\title{
Retinoic Acid Suppresses Parathyroid Hormone (PTH) Secretion and PreproPTH mRNA Levels in Bovine Parathyroid Cell Culture
}

\author{
Paul N. MacDonald, Cindy Ritter, Alex J. Brown, and Eduardo Slatopolsky \\ Renal Division, Department of Medicine, Washington University School of Medicine, St. Louis, Missouri 63110
}

\begin{abstract}
1,25-dihydroxyvitamin $\mathrm{D}_{3}\left[1,25(\mathrm{OH})_{2} \mathrm{D}_{3}\right]$ suppresses parathyroid hormone (PTH) gene transcription. Recent evidence suggests that retinoid $X$ receptors are involved in $1,25(\mathrm{OH})_{2} \mathrm{D}_{3^{-}}$ mediated transcriptional events. However, little data exists for a role of retinoids in parathyroid function or in PTH expression. In the present study, we observed that all-trans- or 9-cis retinoic acid suppressed the release of PTH from bovine parathyroid cell cultures. Both retinoids were remarkably potent with significant decreases evident at $10^{-10} \mathrm{M}$ and a maximally suppressive effect $(\sim 65 \%)$ at $10^{-7} \mathrm{M}$. All-trans-retinol was considerably less potent in this system. The effect was not evident until $12 \mathrm{~h}$, suggesting that retinoids did not affect the rapid secretion of preexisting PTH stores. PreproPTH mRNA levels were also suppressed by retinoic acid and the retinoid potencies were similar to those observed in the secretion studies. Combined treatment with $10^{-6} \mathrm{M}$ retinoic acid and $10^{-8} \mathrm{M}$ $1,25(\mathrm{OH})_{2} \mathrm{D}_{3}$ more effectively decreased $\mathrm{PTH}$ secretion and preproPTH mRNA than did either compound alone. These data indicate that retinoic acid: $(a)$ elicits a bioresponse in bovine parathyroid cells; $(b)$ attenuates PTH expression at the protein and mRNA levels, and (c) acts independently of $1,25(\mathrm{OH})_{2} \mathrm{D}_{3}$ in the control of PTH expression. (J. Clin. Invest. 1994. 93:725-730.) Key words: cholecalciferols $\bullet$ parathyroid glands • retinoids • tretinoin • vitamin A
\end{abstract}

\section{Introduction}

It is well accepted that ionized calcium and 1,25-dihydroxyvi$\operatorname{tamin} \mathrm{D}_{3}\left[1,25(\mathrm{OH})_{2} \mathrm{D}_{3}\right]^{1}$ are the two main regulators of parathyroid hormone (PTH) synthesis and secretion. The action of calcium on PTH secretion is rapid $(<3 \mathrm{~min})$ and that of $1,25(\mathrm{OH})_{2} \mathrm{D}_{3}$ is relatively delayed $(>6 \mathrm{~h})$. In general, serum

The results of this study were presented in part at the American Society for Bone and Mineral Research, 18-22 September 1993, Tampa, FL, and were published in abstract form (1993. J. Bone Miner. Res. 8:174).

Address correspondence and reprint requests to Paul N. MacDonald, Ph.D., Renal Division, Box 8126, Washington University School of Medicine, St. Louis, MO 63110.

Received for publication 26 July 1993 and in revised form 20 September 1993.

1. Abbreviations used in this paper: $1,25(\mathrm{OH})_{2} \mathrm{D}_{3}, 1,25$ dihydroxyvitamin $\mathrm{D}_{3}$; GAPDH, glyceraldehyde 3-phosphate dehydrogenase; PTH, parathyroid hormone; RAR, retinoic acid receptor; RXR, retinoid X receptor; $V D R$, vitamin $D$ receptor.

J. Clin. Invest.

(c) The American Society for Clinical Investigation, Inc.

0021-9738/94/02/725/06 \$2.00

Volume 93, February 1994, 725-730 ionized calcium is important for regulating the minute-to-minute secretion of PTH, while $1,25(\mathrm{OH})_{2} \mathrm{D}_{3}$ is the principal factor that governs the rate of parathyroid hormone synthesis. PTH and preproPTH mRNA levels are decreased in response to $1,25(\mathrm{OH})_{2} \mathrm{D}_{3}(1,2)$, and this response is manifested at the level of PTH gene transcription $(3,4)$. Transcriptional effects of $1,25(\mathrm{OH})_{2} \mathrm{D}_{3}$ are mediated by the vitamin $\mathrm{D}$ receptor (VDR) (5). The VDR functions as a ligand-inducible transcription factor that binds to specific DNA promoter sequences termed vitamin $\mathrm{D}$ responsive elements present in $1,25(\mathrm{OH})_{2} \mathrm{D}_{3}$ responsive gene sequences. Importantly, recent data suggest a role for an additional receptor protein in this mechanism. In this regard, a mammalian nuclear factor is essential for high affinity binding of VDR to vitamin D responsive elements in vitro (6-8). Further studies suggest this factor is related to the retinoid X receptors ( $R X R s$ ), a newly discovered subclass of nuclear receptors that mediate cellular responses to 9-cis retinoic acid (9-11). RXRs form stable heterodimers with VDR in vitro (12-14) and enhance $1,25(\mathrm{OH})_{2} \mathrm{D}_{3}$-dependent transcription in transient expression assays $(14,15)$. Consequently, the possibility exists that retinoids and their receptors also may be involved in $1,25(\mathrm{OH})_{2} \mathrm{D}_{3}$-mediated suppression of PTH gene expression.

There is little data concerning a role for retinoids or their nuclear receptors in the control of PTH expression or in parathyroid function. Currently, it is not known if parathyroid glands express nuclear receptors for retinoids, and there are only a few reports that describe an effect of vitamin A on PTH expression. More than 15 years ago, Chertow et al. (16) reported that vitamin A stimulated PTH secretion from bovine parathyroid slices, and that vitamin A elevated serum PTH in normal human males $1 \mathrm{~h}$ after its administration. In contrast, Frankel et al. (17) demonstrated that rats chronically intoxicated with vitamin A had undetectable levels of serum PTH, suggesting that hypervitaminosis A suppressed PTH secretion in vivo.

In the present study, we examined direct effects of retinoids on PTH expression in bovine parathyroid cell culture. We show, for the first time, that retinoic acid potently inhibits PTH synthesis at the level of preproPTH mRNA in this system. The suppressive effect of retinoids was evident at physiologic concentrations and was remarkably similar to the suppression of PTH mediated by $1,25(\mathrm{OH})_{2} \mathrm{D}_{3}$. These data suggest a role for retinoids in parathyroid gland function and, specifically, in the regulation of PTH expression.

\section{Methods}

Primary cell cultures. Primary monolayer cultures of bovine parathyroid cells were prepared according to the method of MacGregor et al. (18), with minor modifications. Briefly, bovine parathyroid glands were trimmed of extraneous fatty tissue, sliced to $0.5-\mathrm{mm}$ thickness with a tissue slicer (Stadie Riggs; Thomas Scientific, Swedesboro, NJ), and placed in a 50/50 mixture of DME/Hamm's F-12 medium con- 
taining $2.5 \mathrm{mg} / \mathrm{ml}$ collagenase (Boehringer Mannheim Corp., Indianapolis, IN) and $0.5 \mathrm{mM}$ total calcium. The suspension ( $1 \mathrm{~g}$ tissue $/ 10$ $\mathrm{ml}$ media) was agitated in a shaking water bath at $37^{\circ} \mathrm{C}$ for $90 \mathrm{~min}$ and periodically aspirated through a large bore hole cut in an Eppendorf pipet tip attached to a $60-\mathrm{ml}$ syringe. The digested tissue was filtered through gauze, resuspended, and washed three times with culture medium containing DME/Hamm's F-12 (50:50), 1 mM total calcium, $4 \%$ newborn calf serum, $15 \mathrm{mM}$ Hepes, $100 \mathrm{IU} / \mathrm{ml}$ penicillin, 100 $\mu \mathrm{g} / \mathrm{ml}$ streptomycin, $5 \mu \mathrm{g} / \mathrm{ml}$ insulin, $2 \mathrm{mM}$ glutamine, and $1 \%$ nonessential amino acids. Cells were plated at 80,000 cells $/ \mathrm{cm}^{2}$. After $24 \mathrm{~h}$, the medium was replaced with the same medium described above, with the exception that the serum was replaced with $1 \mathrm{mg} / \mathrm{ml}$ bovine serum albumin and $5 \mu \mathrm{g} / \mathrm{ml}$ holo-transferrin. Thereafter, this serum-free medium was replenished every $24 \mathrm{~h}$.

PTH secretion. Treatment media were prepared by adding the appropriate concentration of ethanol vehicle, $1,25(\mathrm{OH})_{2} \mathrm{D}_{3}$ or retinoids to serum-free culture media. The concentration of ethanol was always below $0.1 \%$. Monolayers were cultured in 12-well plates and maintained in treatment media for the indicated periods of time with media changes every $24 \mathrm{~h}$. To examine PTH, the monolayers were washed three times with Dulbecco's PBS and then incubated with fresh treatment media for $3 \mathrm{~h}$. Media were collected on ice, centrifuged, and supernatants were stored at $-20^{\circ} \mathrm{C}$ for PTH analysis. The monolayers were washed with Dulbecco's PBS, dissolved in $0.1 \mathrm{~N} \mathrm{NaOH}$, and stored at $-20^{\circ} \mathrm{C}$ for cellular protein analysis. Protein concentration was measured using a protein assay kit (Bio-Rad Laboratories, Richmond, CA ). Immunoreactive PTH was assayed using antiserum $\mathrm{CH} 9$ as described previously (19). A two-tailed $t$ test was used to analyze the data as indicated.

Northern analysis. Bovine parathyroid cell monolayers were solubilized in RNAzol (Cinna/Biotecx, Friendswood, TX) and total RNA was extracted according to the manufacturer's protocol. Total RNA (generally 3-8 $\mu \mathrm{g}$ ) was separated on a $1.5 \%$ agarose/formaldehyde gel and transferred to a membrane (Nytran; Schleicher \& Schuell, Keene, $\mathrm{NH}$ ) by capillary action. cDNA probes for bovine parathyroid hormone (generously provided by Dr. Byron Kemper, University of Illinois College of Medicine, Urbana, IL) and human glyceraldehyde 3-phosphate dehydrogenase (GAPDH) were labeled with a random primer kit (Boehringer Mannheim Corp.) using [ $\left.{ }^{32} \mathrm{P}\right] \mathrm{dCTP}$ and the Klenow fragment of DNA polymerase I. The membrane was hybridized with ${ }^{32}$ P-labeled probes as described (20). Sequential probing with multiple cDNAs was accomplished by stripping the membrane in $50 \%$ formamide, at $65^{\circ} \mathrm{C}$ for $3 \mathrm{~h}$ between hybridizations.

\section{Results}

Retinoic acid suppresses PTH secretion in bovine parathyroid cell culture. Based on the ability of RXRs and 9-cis retinoic acid to participate in selected vitamin D-mediated transcriptional events $(14,15,21)$, studies were initiated to determine if retinoic acid influenced vitamin D-mediated suppression of PTH expression. Our initial approach examined the effect of retinoids and $1,25(\mathrm{OH})_{2} \mathrm{D}_{3}$ on secretion of immunoreactive PTH from bovine parathyroid cells in culture. The results are illustrated in Fig. 1. After a 72 -h treatment with $10 \mathrm{nM}$ $1,25(\mathrm{OH})_{2} \mathrm{D}_{3}$, PTH secretion was reduced $\sim 40 \%$ compared to vehicle treated controls. Treatment of bovine parathyroid cells with $1 \mu \mathrm{M}$ 9-cis retinoic acid also effectively suppressed PTH secretion $(\sim 45 \%)$ in this system. When the cells were incubated with $1,25(\mathrm{OH})_{2} \mathrm{D}_{3}$ and 9-cis retinoic acid together, a further decrease was observed beyond that obtained with either compound alone. This combined treatment suppressed PTH secretion by $>60 \%$ compared to vehicle-treated controls.

9-cis retinoic acid suppresses PTH secretion in a time- and dose-dependent fashion. A suppressive effect of retinoic acid on PTH secretion from parathyroid cells has not been reported

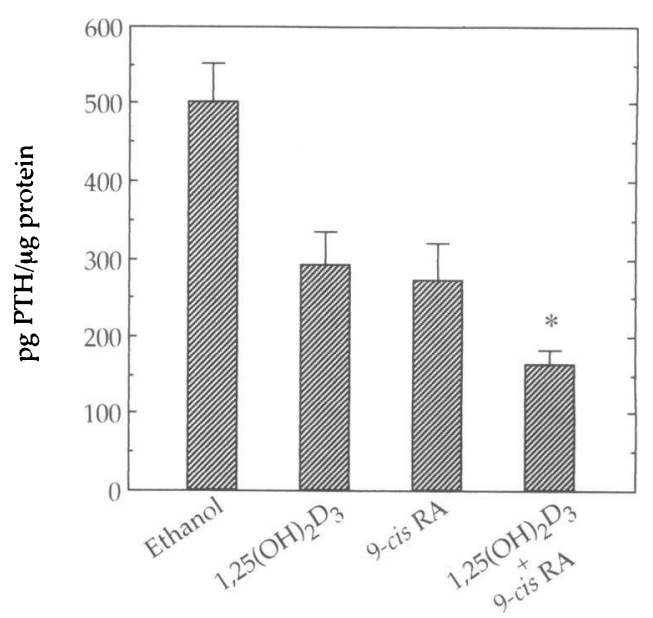

Figure 1. 9-cis retinoic acid suppresses PTH secretion in vitro. Bovine parathyroid cells were cultured as described. On the 3 rd d in culture, replicate wells $(n=6)$ were treated with or without $1 \mu \mathrm{M} 9$-cis retinoic acid in the presence or absence of $10 \mathrm{nM} 1,25(\mathrm{OH})_{2} \mathrm{D}_{3}$. After a 72-h treatment, the monolayers were washed, replenished with fresh media, and then media were collected $3 \mathrm{~h}$ later for PTH determinations by radioimmunoassay. PTH values were normalized to total cellular protein per well. The data are from a single representative experiment, in which each value is the mean $\pm \mathrm{SEM}$. *Value obtained for the cotreatment group [9-cis $\mathrm{RA}+1,25(\mathrm{OH})_{2} \mathrm{D}_{3}$ ] was signifcantly different from the PTH values obtained with 9-cis retinoic acid or $1,25(\mathrm{OH})_{2} \mathrm{D}_{3}$ treatment alone $(P<0.001)$.

previously. Therefore, we further characterized the retinoid effect with respect to time, dose, and retinoid specificity (Fig. 2). As illustrated in Fig. $2 \mathrm{~A}$, there was no statistically significant effect of retinoic acid on PTH secretion from parathyroid cells during 1-6 h, suggesting that retinoic acid did not alter rapid secretion of preexisting stores of PTH in this system. The suppressive effect was first apparent after a 12-h treatment with retinoic acid $(25 \%$ inhibition; $P<0.002)$ and was decreased $>60 \%$ by $72 \mathrm{~h}$.

Because of potential isomerization of 9-cis retinoic acid to the all-trans isomer, it is possible that all-trans retinoic acid might elicit a similar response. In the experiment shown in Fig. $2 B$, we compared the dose response of various retinoid compounds on PTH secretion in this system. We noted that 9-cis retinoic acid and all-trans retinoic acid were similar and remarkably potent suppressors of PTH release with significant effects apparent at $10^{-10} \mathrm{M}$. A maximal effect $(\sim 65 \%$ inhibition) for both retinoids was observed at $10^{-7} \mathrm{M}$ concentrations. This dose response curve is remarkably similar to that observed in retinoic acid-mediated transcription studies ( 10 , 11 ). In contrast, all-trans retinol was consistently less potent at affecting PTH secretion under these conditions. Significant suppression with the alcohol isomer was not observed except at $1 \mu \mathrm{M}$ concentrations during the $72-\mathrm{h}$ treatment period.

Retinoids suppress the steady state levels of preproPTH $m R N A$ in bovine parathyroid cell culture. To determine if the effects of retinoids were also apparent at the steady state mRNA level for preproPTH, parathyroid cells were cultured in the absence or presence of retinoic acid or $1,25(\mathrm{OH})_{2} \mathrm{D}_{3}$. Total RNA was isolated and analyzed in Northern blot protocols. The results of a typical experiment are illustrated in Fig. 3. We noted consistent suppression of preproPTH transcript levels with $1,25(\mathrm{OH})_{2} \mathrm{D}_{3}$ or retinoic acid when compared to GAPDH 
A

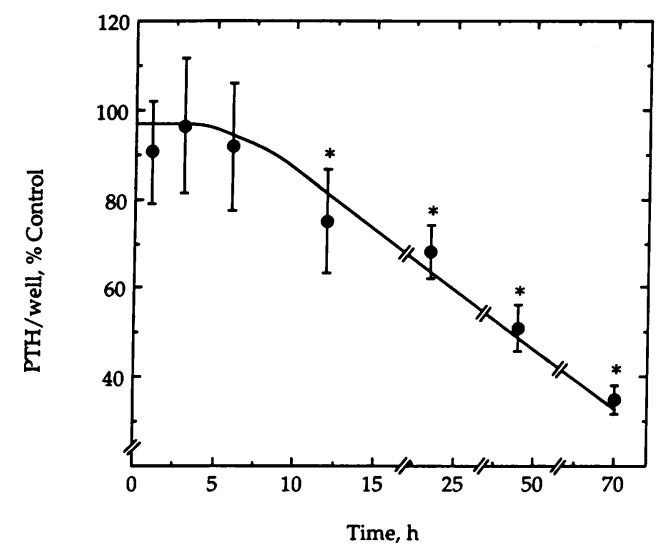

B

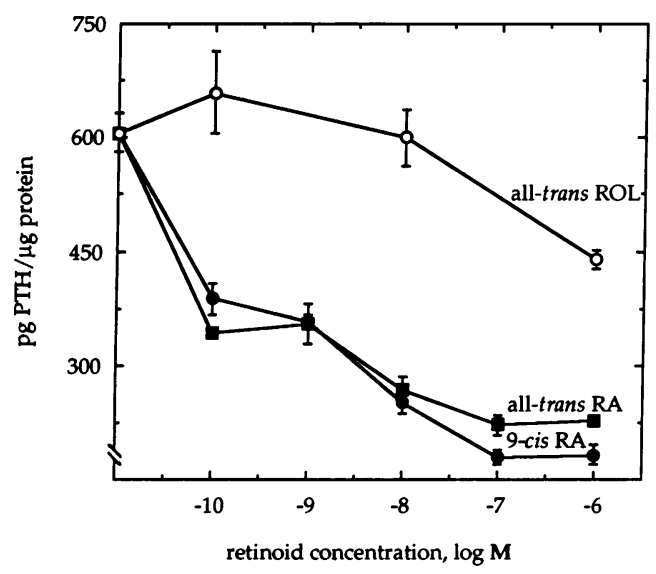

Figure 2. Retinoic acid suppresses PTH secretion in a time and dose dependent fashion. $(A)$ Time-dependent inhibition of PTH secretion by 9 -cis retinoic acid in bovine parathyroid cell culture. Parathyroid cells were treated with ethanol vehicle or with $10^{-6} \mathrm{M}$ 9-cis retinoic acid. At various times after treatment, vehicle-treated controls and retinoid-treated monolayers were assayed for PTH secretion. The data are presented as percent of control that is defined as [ ( pg PTH in the retinoic acid treated group/pg PTH in the vehicle treated group) $\times 100$ ]. The values are the mean \pm the normalized SD of the retinoic acid-treated group $(n=6)$. ${ }^{*}$ Data points in which $P<0.002$ as assessed by the Student's $t$ test. $(B)$ Dose-dependent inhibition of PTH secretion by retinoic acid. Bovine parathyroid cell monolayers were treated with increasing concentrations of 9-cis retinoic acid (solid circles), all-trans retinoic acid (solid squares), or all-trans retinol (open circles) for $72 \mathrm{~h}$. PTH was assayed in the media after a 3-h secretion period. The data are presented as the mean $\pm \operatorname{SD}(n=6)$.

transcript levels (inset). Scanning densitometry revealed a 75 and $70 \%$ reduction in the preproPTH/GAPDH ratio with $1,25(\mathrm{OH})_{2} \mathrm{D}_{3}$ and 9 -cis retinoic acid, respectively.

In the experiment shown in Fig. 4, we compared the time dependence of $1,25(\mathrm{OH})_{2} \mathrm{D}_{3}$ - and 9-cis retinoic acid-mediated suppression on preproPTH transcript levels in bovine parathyroid cell culture. Both compounds required approximately the same time frame to elicit their individual effects. Marked suppression of preproPTH transcripts relative to GAPDH transcripts was observed after a 24-h treatment with either $1,25(\mathrm{OH})_{2} \mathrm{D}_{3}$ or 9 -cis retinoic acid. Earlier times $(12 \mathrm{~h})$ did not consistently reveal suppression with either compound

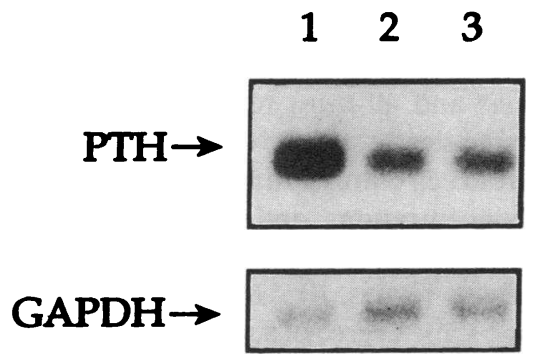

Figure 3. 9-cis retinoic acid and $1,25(\mathrm{OH})_{2} \mathrm{D}_{3}$ decrease steady state levels of preproPTH mRNA in bovine parathyroid cell culture. Bovine parathyroid cells were incubated with ethanol vehicle (lane 1), with $10^{-6} \mathrm{M}$ 9-cis retinoic acid (lane 2),

or with $10^{-8} \mathrm{M} 1,25(\mathrm{OH})_{2} \mathrm{D}_{3}$ (lane 3) for $72 \mathrm{~h}$. Total RNA was extracted and analyzed by standard Northern blot protocols. The membrane was probed with ${ }^{32} \mathrm{P}$-labeled cDNA for bovine PTH. After autoradiographic exposure, the membrane was stripped as described in Methods and reprobed with ${ }^{32} \mathrm{P}$-labeled cDNA for human GAPDH.

(data not shown). However, with prolonged treatments, further decreases in PTH transcript levels were apparent, with a maximal effect observed at $72 \mathrm{~h}$. At 48 and $72 \mathrm{~h}$, further suppression of preproPTH mRNA was consistently observed in cells cotreated with $1,25(\mathrm{OH})_{2} \mathrm{D}_{3}$ and 9-cis retinoic acid compared to cells treated with the individual vitamins alone.

Next, we compared the ability of all-trans retinoic acid,

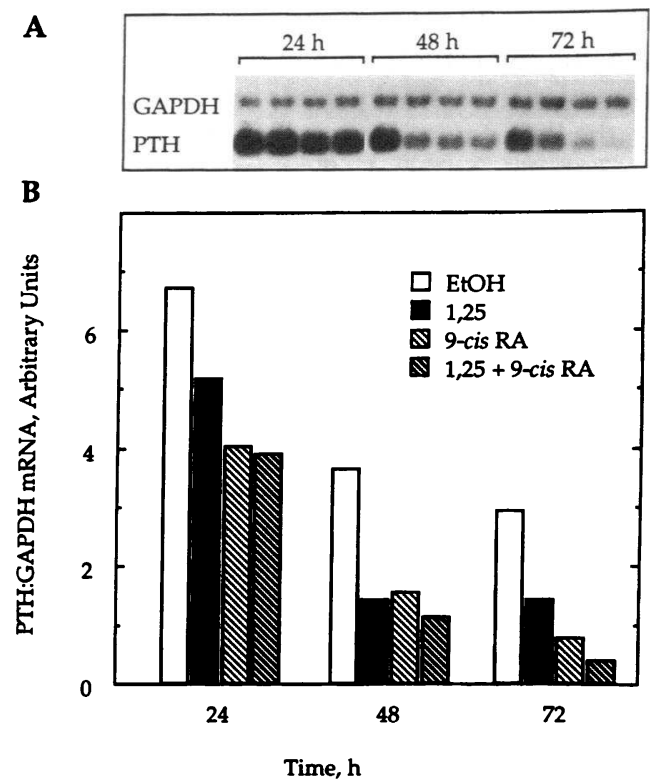

Figure 4. Time course for suppressive effects of retinoic acid and $1,25(\mathrm{OH})_{2} \mathrm{D}_{3}$ on preproPTH mRNA levels in parathyroid cells. Parathyroid cells were incubated with ethanol vehicle (open bars), $10^{-8} \mathrm{M} 1,25(\mathrm{OH})_{2} \mathrm{D}_{3}$ (solid bars), $10^{-6} \mathrm{M}$ 9-cis retinoic acid (light stippled bars), or with a combination of $10^{-8} \mathrm{M} 1,25(\mathrm{OH})_{2} \mathrm{D}_{3}$ and $10^{-6} \mathrm{M}$ 9-cis retinoic acid (dark stippled bars) for 24,48 , or $72 \mathrm{~h}$. At the indicated times, total RNA was isolated and subjected to Northern blot analysis. $(A)$ Autoradiographic results after sequential probing with labeled bovine PTH cDNA followed by hGAPDH cDNA. Exposure times were 2 and $8 \mathrm{~h}$, respectively. The lanes from left to right at each time point are ethanol, $1,25(\mathrm{OH})_{2} \mathrm{D}_{3}, 9$-cis retinoic acid, and the combination of $1,25(\mathrm{OH})_{2} \mathrm{D}_{3}$ and 9-cis retinoic acid. $(B)$ The quantitation obtained by scanning densitometry of the autoradiogram in $A$. Results are presented as the peak area of the PTH signal divided by the peak area of the GAPDH signal. 
9-cis retinoic acid, and all-trans retinol to suppress preproPTH transcript levels (Fig. 5). As seen previously in the secretion studies (Fig. 2), both 9-cis and all-trans retinoic acid were equally effective at decreasing steady state levels of preproPTH mRNA in bovine parathyroid cell culture. Marked suppression was evident at $10^{-10} \mathrm{M}$ concentrations, and the acid isomers were more than 100 -fold more effective than retinol in mediating the response in this system. That is, $10^{-6} \mathrm{M}$ all-trans retinol was required to produce the same degree of suppression as seen with $10^{-8} \mathrm{M}$ retinoic acid.

Fig. 6 compares the dose response of 9 -cis retinoic acid in the absence and presence of $10^{-8} \mathrm{M} 1,25(\mathrm{OH})_{2} \mathrm{D}_{3}$. The results show that addition of $1,25(\mathrm{OH})_{2} \mathrm{D}_{3}$ results in further suppression of PTH transcript levels at every concentration of 9-cis retinoic acid examined. Thus, when cells are treated with the combination of $10^{-7} \mathrm{M}$ retinoic acid and $10^{-8} \mathrm{M}$ $1,25(\mathrm{OH})_{2} \mathrm{D}_{3}$, preproPTH mRNA levels are reduced by $>70 \%$. This is compared to $\sim 50 \%$ reductions observed in this experiment with either compound alone. Moreover, we observed that $10^{-8} \mathrm{M} 9$-cis retinoic acid produced approximately the same degree of inhibition of preproPTH mRNA levels as $10^{-8} \mathrm{M} 1,25(\mathrm{OH})_{2} \mathrm{D}_{3}$.

\section{Discussion}

The experimental results clearly show that in bovine parathyroid cell cultures, retinoic acid is a potent inhibitor of PTH synthesis. Retinoic acid-mediated suppression is evident at the steady state level of preproPTH mRNA and is also reflected in the amount of immunoreactive PTH peptide released from the cell. Interestingly, the time course, dose response, and relative magnitude of the retinoid-mediated effect at both the PTH peptide and preproPTH mRNA levels closely parallel the inhi-
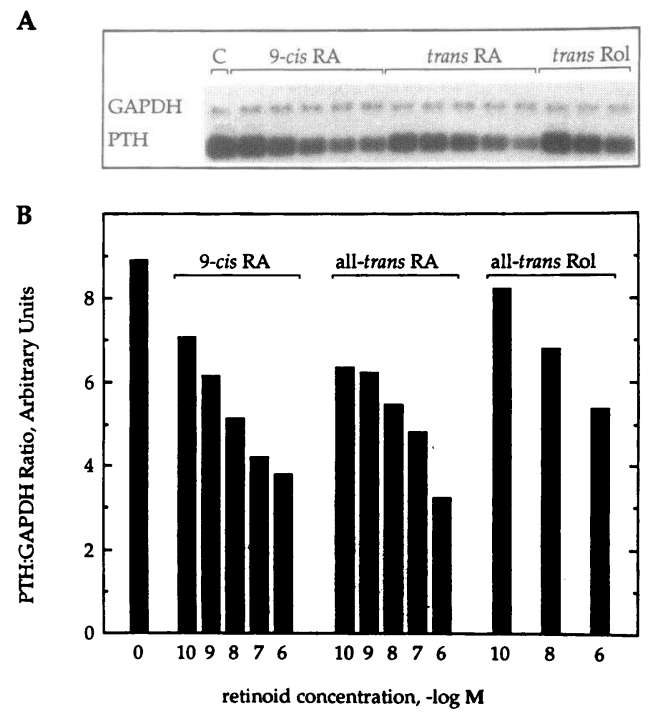

Figure 5. Retinoic acid isomers selectively suppress preproPTH mRNA levels in bovine parathyroid cell cultures. Parathyroid cells were incubated with increasing concentrations of 9-cis retinoic acid, all-trans retinoic acid, or all-trans retinol for $72 \mathrm{~h}$. Total RNA was isolated and subjected to Northern blot analysis with ${ }^{32} \mathrm{P}$-labeled cDNAs for bovine PTH or human GAPDH. The resulting autoradiograms $(A)$ were quantitated by densitometry and the results are presented graphically as PTH/GAPDH ratios in relative densitometric units $(B)$.

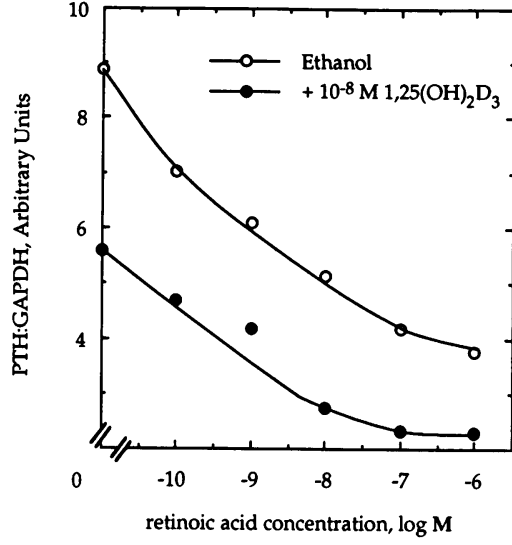

Figure 6. Retinoic acid further suppresses preproPTH transcript levels after treatment of parathyroid cells with $10^{-8} \mathrm{M} 1,25(\mathrm{OH})_{2} \mathrm{D}_{3}$. Bovine parathyroid cell cultures were incubated with increasing concentrations of 9-cis retinoic acid in the absence (open circles) or presence (closed circles) of $10^{-8} \mathrm{M} 1,25(\mathrm{OH})_{2} \mathrm{D}_{3}$. After a 72-h treatment, total RNA was isolated and subjected to Northern blot analysis. The resulting autoradiogram was quantitated by scanning densitometry, and the results are plotted as the PTH/GAPDH ratio in relative densitometric units.

bition seen with $1,25(\mathrm{OH})_{2} \mathrm{D}_{3}$, a well-documented suppressor of PTH gene transcription. Both retinoic acid and $1,25(\mathrm{OH})_{2} \mathrm{D}_{3}$ reduced PTH secretion and preproPTH transcript levels to similar extents at $10 \mathrm{nM}$ concentrations (Figs. 2 and 6 ), and both compounds required $\sim 24 \mathrm{~h}$ to affect transcript levels (Fig. 4) under the conditions used in this study. Therefore, within the context of this system, it appears that retinoic acid and $1,25(\mathrm{OH})_{2} \mathrm{D}_{3}$ are equally effective suppressors of PTH expression. Moreover, significant suppression of PTH secretion and preproPTH transcript levels were consistently observed with nanomolar concentrations of retinoic acid. Since serum concentrations of retinoic acid are on the order of $10 \mathrm{nM} \mathrm{(22),} \mathrm{it} \mathrm{is} \mathrm{apparent} \mathrm{that} \mathrm{marked} \mathrm{suppression} \mathrm{of}$ PTH occurs with physiologic concentrations of retinoic acid in this in vitro system.

Understanding the precise mechanism through which retinoids mediate inhibition of PTH expression will require further study. However, this initial report demonstrates that retinoids do not affect the rapid secretion of preexisting PTH stores, as is the case with calcium ion (23). This is based on the observation that a minimum of $12 \mathrm{~h}$ is required to observe a statistically significant effect of retinoids on the release of PTH. A part of the mechanism certainly involves PTH synthesis, primarily because of alterations at the preproPTH mRNA level. These alterations in preproPTH transcripts might arise through transcriptional repression of the PTH gene via the nuclear receptors for retinoids; for example, retinoic acid receptors (RARs) or RXRs. A similar mechanism involving VDR results in transcriptional suppression of the PTH gene by $1,25(\mathrm{OH})_{2} \mathrm{D}_{3}$ in vivo (4). Alternatively, retinoids may act through RARs or RXRs to decrease the stability or enhance the degradation of the preproPTH transcript. Altered transcript stability has a predominant role in the regulation of vitellogenin mRNA transcripts by estradiol and the estrogen receptor (24). Finally, since PTH release is affected at $12 \mathrm{~h}$, and alterations in preproPTH transcript levels are not consistently apparent until $24 \mathrm{~h}$, it is likely that other regulatory mechanisms (e.g., translational controls) may play a role in the control of PTH expression by retinoids.

Until the present study, the parathyroid gland was not generally considered a target organ for vitamin A or retinoids. It has not yet been established whether the nuclear receptors that mediate the pleotropic effects of vitamin A are expressed in the 
parathyroid gland. However, we have obtained preliminary evidence that human parathyroid glands express transcripts for RXR $\alpha$ (MacDonald, P., C. Ritter, A. Brown, and E. Slatopolsky, unpublished observation). There has been little evidence for a direct biological response of parathyroid cells to retinoids. The study of Frankel et al. (17) showed reduced serum PTH in rats administered high doses of retinoids suggesting that hypervitaminosis A may suppress PTH expression in vivo. That study was complicated by hypercalcemia in the vitamin A-intoxicated animals, presumably caused by the effects of vitamin A on bone and its ability to mobilize bone calcium (25-28). Thus, decreased PTH in hypervitaminosis A may be secondary to increased serum calcium caused by the action of vitamin A on bone. Importantly, our in vitro studies with bovine parathyroid cells strongly support a direct role for retinoids in the regulation of PTH expression. We show in vitro that retinoic acid-mediated suppression of $\mathrm{PTH}$ occurs independent of calcium and independent of $1,25(\mathrm{OH})_{2} \mathrm{D}_{3}$, the two major regulators of PTH expression. Therefore, our studies suggest that the parathyroid gland is a target organ for retinoid action and, specifically, they provide strong evidence that retinoids are involved in the synthesis of PTH.

Based on the specificity and dose response profiles, we can not distinguish between the effects of all-trans retinoic acid or 9-cis retinoic acid, but clearly the acid isoforms are 100-fold more potent than all-trans retinol. This specificity is a clear indication that the suppression observed in this report is not caused by generalized effects of these fat-soluble compounds on the in vitro parathyroid cell system. Moreover, the observation that all-trans and 9-cis retinoic acid are equipotent implies that the suppressive effect may be mediated predominantly through the RARs and not through the RXRs. This is based on the observation that 9-cis retinoic acid is specific for RXR-mediated events $(10,11)$, while both the trans and cis isomers of retinoic acid are effective ligands for RAR-dependent mechanisms (29). One caveat to this line of reasoning is that the parathyroid cells may express enzymes that isomerize retinoic acid, which would confound the interpretation of these data. Such isomerases are expressed in the visual system that act on retinol to regenerate the visual chromophore $(30,31)$.

Metabolism of retinoids in the bovine parathyroid cell system may also explain why micromolar concentrations of alltrans retinol suppressed PTH secretion and PTH transcript levels. It is possible that the parathyroid cells express the enzymatic machinery required to oxidize all-trans retinol to the more active acid isoforms. Recent evidence for a cytosolic dehydrogenase that generates retinoic acid in several vitamin A-responsive tissues was described (32). Thus, during the 72-h treatment period, micromolar concentrations of all-trans retinol may be converted to a more active form, such as retinoic acid, which then acts within the parathyroid cell to decrease PTH expression. Further studies that examine retinoid metabolism or endogenous vitamin A stores also would provide sustantive proof that the parathyroid is an important target for the effects of retinoids in vivo.

Our results also indicate a possible therapeutic application of retinoids to the treatment of hyperparathyroidism. In the United States alone, more than 40,000 men and women each year develop end-stage renal failure. It is well established that, with progressive loss of renal mass and function, nearly all these patients develop secondary hyperparathyroidism, a pathological state characterized by an enlarged parathyroid gland and supranormal levels of serum PTH. A primary clinical target in these patients is the parathyroid gland and the control of PTH secretion. In fact, the suppressive effect of $1,25(\mathrm{OH})_{2} \mathrm{D}_{3}$ on PTH has led to its use in the treatment of secondary hyperparathyroidism (33). In many cases, this treatment is not absolute, since serum PTH levels are markedly lower, but still well above the normal range. Therefore, defining the role of other agents that suppress PTH secretion or synthesis may lead to the development of even more effective treatments to combat this condition. Should future studies reveal that the in vitro effects observed in this report also have relevance in vivo, then it is highly probable that with the continuing development of low toxic retinoid analogues, a new therapeutic potential may be considered in the treatment of secondary hyperparathyroidism.

\section{Acknowledgments}

We graciously acknowledge Dr. Byron Kemper at the University of Illinois College of Medicine at Urbana-Champaign for the generous gift of the bovine PTH cDNA. We are also grateful to Dr. Milan R. Uskokovic' and Dr. Arthur A. Levine at Hoffmann-LaRoche (Nutley, NJ) for generously providing the $1,25(\mathrm{OH})_{2} \mathrm{D}_{3}$ and 9-cis retinoic acid, respectively.

This work was supported in part by grants DK-09976, DK-30178, and DK-07126 from the National Institute of Diabetes and Digestive and Kidney Diseases at the National Institutes of Health.

\section{References}

1. Cantley, K. L., J. Russell, D. Lettieri, and L. M. Sherwood. 1985. 1,25-Dihydroxyvitamin $\mathrm{D}_{3}$ suppresses parathyroid hormone secretion from bovine parathyroid cells in tissue culture. Endocrinology. 117:2114.

2. Silver, J., J. Russel, D. Lettieri, and L. M. Sherwood. 1985. Regulation by vitamin D metabolites of messenger ribonucleic acid for preproparathyroid hormone in isolated bovine parathyroid cells. Proc. Natl. Acad. Sci. USA. 82:42704273.

3. Russell, J., D. Lettieri, and L. M. Sherwood. 1986. Suppression by $1,25(\mathrm{OH})_{2} \mathrm{D}_{3}$ of transcription of the pre-proparathyroid hormone gene. Endocrinology: 119:2864-2866.

4. Silver, J., T. Navey-Many, H. Mayer, H. J. Schmelzer, and M. M. Popovtzer. 1986. Regulation by vitamin D metabolites of parathyroid hormone gene transcription in vivo in the rat. J. Clin. Invest. 78:1296-1301.

5. Haussler, M. R., C. M. Terpening, B. S. Komm, G. K. Whitfield, and C. A. Haussler. 1988. Vitamin D hormone receptors: structure, regulation and molecular function. In Vitamin D: Molecular, Cellular and Clinical Endocrinology. A. W. Norman, K. Schaefer, H.-G. Grigoleit, and D. V. Herrath, editors. Walter de Gruyter, Berlin. pp. 205-214.

6. Liao, J., K. Ozono, T. Sone, D. P. McDonnell, and J. W. Pike. 1990. Vitamin D receptor interaction with specific DNA requires a nuclear protein and 1,25-dihydroxyvitamin $\mathrm{D}_{3}$. Proc. Natl. Acad. Sci. USA. 87:9751-9755.

7. Sone, T., S. Kerner, and J. W. Pike. 1991. Vitamin D receptor interaction with specific DNA: association as a 1,25-dihydroxyvitamin $D_{3}$-modulated heterodimer. J. Biol. Chem. 266:23296-23305.

8. MacDonald, P. N., C. A. Haussler, C. M. Terpening, M. A. Galligan, M. C. Reeder, G. K. Whitfield, and M. R. Haussler. 1991. Baculovirus-mediated expression of the human vitamin D receptor. J. Biol. Chem. 266:18808-18813.

9. Mangelsdorf, D. J., E. S. Ong, J. A. Dyck, and R. M. Evans. 1990. Nuclear receptor that identifies a novel retinoic acid response pathway. Nature (Lond.). 345:224-229.

10. Levin, A. A., L. J. Sturzenbecker, S. Kazmer, T. Bosakowski, C. Huselton, G. Allenby, J. Speck, C. L. Kratzeisen, M. Rosenberger, A. Lovey, and J. F. Grippo. 1992. 9-Cis retinoic acid stereoisomer binds and activates the nuclear receptor $\operatorname{RXR} \alpha$. Nature (Lond.). 355:359-361.

11. Heyman, R. A., D. J. Mangelsdorf, J. A. Dyck, R. B. Stein, G. Eichele, R. M. Evans, and C. Thaller. 1992.9-Cis retinoic acid is a high affinity ligand for the retinoid X receptor. Cell. 68:397-406.

12. Bugge, T. H., J. Pohl, O. Lonnoy, and H. G. Stunnenberg. 1992. RXR $\alpha$, a promiscuous partner of retinoic acid and thyroid hormone receptors. $E M B O$ (Eur. Mol. Biol. Organ.) J. 11:1409-1418.

13. Kliewer, S. A., K. Umesono, D. J. Mangelsdorf, and R. M. Evans. 1992. Retinoid $\mathrm{X}$ receptor interacts with nuclear receptors in retinoic acid, thyroid hormone, and vitamin $\mathrm{D}_{3}$ signalling. Nature (Lond.). 355:446-449. 
14. Yu, V. C., C. Delsert, B. Andersen, J. M. Holloway, O. V. Devary, A. M. Naar, S. Y. Kim, J.-M. Boutin, C. K. Glass, and M. G. Rosenfeld. 1991. RXRß: a coregulator that enhances binding of retinoic acid, thyroid hormone, and vitamin D receptors to their cognate response elements. Cell. 67:1251-1266.

15. MacDonald, P. N., D. R. Dowd, S. Nakajima, M. A. Galligan, M. C. Reeder, C. A. Haussler, K. Ozato, and M. R. Haussler. 1993. Retinoid X receptors stimulate and 9-cis retinoic acid inhibits 1,25-dihydroxyvitamin $\mathrm{D}_{3}$-activated expression of the rat osteocalcin gene. Mol. Cell. Biol. 13:5907-5917.

16. Chertow, B. S., G. A. Williams, R. M. Norris, G. R. Baker, and G. K. Hargis. 1977. Vitamin A stimulation of parathyroid hormone: interactions with calcium, hydrocortisone, and vitamin $\mathrm{E}$ in bovine parathyroid tissues and effects of vitamin A in man. Eur. J. Clin. Invest. 7:307-314.

17. Frankel, T. L., M. S. Seshadri, D. B. McDowall, and C. J. Cornish. 1986. Hypervitaminosis $\mathrm{A}$ and calcium-regulating hormones in the rat. J. Nutr. 116:578-587.

18. MacGregor, R. R., M. P. Sarras, A. Houle, and D. V. Cohn. 1983. Primary monolayer cell culture of bovine parathyroids: effects of calcium isoproterenol and growth factors. Mol. Cel: Endocrinol. 30:313-328.

19. Hruska, K. A., R. Konelman, W. E. Rutherford, S. Klahr, and E. Slatopolsky. 1975. Metabolism of immunoreactive parathyroid hormone in the dog. The role of the kidney and the effects of chronic renal disease. J. Clin. Invest. $56: 39-48$.

20. Meyer, J., C. S. Fullmer, R. H. Wasserman, B. S. Komm, and M. R. Haussler. 1992. Dietary restriction of calcium, phosphorus, and vitamin D elicits differential regulation of the mRNAs for avian intestinal calbindin- $D_{28 \mathrm{k}}$ and the 1,25-dihydroxyvitamin $\mathrm{D}_{3}$ receptor. J. Bone Miner. Res. 7:441-448.

21. Carlberg, C., I. Bendik, A. Wyss, E. Meier, L. J. Sturzenbecker, J. F. Grippo, and W. Hunziker. 1993. Two nuclear signalling pathways for vitamin D. Nature (Lond.). 361:657-660.

22. DeRuyter, M. G., W. E. Lambert, and A. P. DeLeenheer. 1979. Retinoic acid: an endogenous compound of human blood. Unequivocal demonstration of endogenous retinoic acid in normal physiological conditions. Anal. Biochem. 98:402-409.

23. Mayer, G. P., and J. G. Hurst. 1978. Sigmoidal relationship between parathyroid hormone secretion rate and plasma calcium concentration in calves. Endocrinology. 102:1036-1042.

24. Nielsen, D. A., and D. J. Shapiro. 1990. Estradiol and estrogen receptordependent stabilization of a minivitellogenin mRNA lacking 5100 nucleotides of coding sequence. Mol. Cell. Biol. 10:371-376.

25. Wieland, R. G., F. H. Henricks, Y. Amat, F. Leon, L. Gutierrez, and J. C. Jones. 1971. Hypervitaminosis A with hypercalcemia. Lancet. i:698-699.

26. Trechsel, U., A. Stutzer, and H. Fleisch. 1987. Hypercalcemia induced with an arotinoid in thyroparathyroidectomized rats. New model to study bone resorption in vivo. J. Clin. Invest. 80:1679-1686.

27. Katz, C. M., and M. Tzagournis. 1972. Chronic adult hypervitaminosis A with hypercalcemia. Metabolism. 21:1171-1176.

28. Hough, S., L. V. Avioli, H. Muir, D. Gelderblom, G. Jenkins, H. Kurasi, E. Slatopolsky, M. A. Bergfeld, and S. L. Teitelbaum. 1988. Effects of hypervitaminosis A on the bone and mineral metabolism of the rat. Endocrinology. 122:2933-2939.

29. Durand, B., M. Saunders, P. Leroy, M. Leid, and P. Chambon. 1992. All-trans and 9-cis retinoic acid induction of CRABPII transcription is mediated by RAR-RXR heterodimers bound to DR1 and DR2 repeated motifs. Cell. 71:73-85.

30. Berstein, R. R., W. C. Law, and R. R. Rando. 1987. Isomerization of all-trans retinoids to $11-c i s$ retinoids in vitro. Proc. Natl. Acad. Sci. USA. 84:1849-1853.

31. Berstein, P. S., and R. R. Rando. 1986. In vivo isomerization of all-transto 11-cis retinoid in the eye occurs at the alcohol oxidation state. Biochemistry. 25:6473-6478.

32. Posch, K. C., R. D. Burns, and J. L. Napoli. 1992. Biosynthesis of alltrans-retinoic acid from retinal. Recognition of retinal bound to cellular retinol binding protein (type $I$ ) as substrate by a purified cytosolic dehydrogenase. $J$. Biol. Chem. 267:19676-19682.

33. Slatopolsky, E., C. Weerts, J. Thielan, R. Horst, H. Harter, and K. J. Martin. 1984. Marked suppression of secondary hyperparathyroidism by intravenous administration of 1,25-dihydroxycholecalciferol in uremic patients. J. Clin. Invest. 74:2136-2143. 